\title{
Analisis Hukum Administrasi Terhadap Kebijakan Pemerintah Mengenai Pembebasan Biaya Sertifikasi Tanah Wakaf
}

\author{
Islamiyati \\ Fakultas Hukum Universitas Diponegoro Semarang \\ J1. Prof. Sudharto No. 1 Semarang \\ E-mail: Islamiyati@yahoo.co.id
}

\begin{abstract}
Abstrack
The study analyzed Article 22 of Government Regulation Number 13 of 2010 concerning government policies for the exemption of waqf land certification fees according to state administrative law. The analyze focus on the reasons for the government to issue such policies in the perspective of the state administrative law. The research type of library research requires secondary data, which consists of primary, secondary and tertiary legal materials, normative juridical approaches, and qualitative data analysis. The results of the study explained that the government issued a policy of freeing the cost of waqf land certificates aimed at empowering waqf land so that its designation could be felt by the community, accelerating the legality of waqf land, protecting and securing and optimizing the benefits of waqf assets. This policy is an effort to understand waqf deeds which means worship and legal certainty. Government policy is the implementation of the function of the state administrative law in creating a government that is clean and in accordance with the principles of good general governance, namely; the principles of legality, equality, justice, legal protection, wisdom, implementation of public interest, and acting meticulously.
\end{abstract}

Key Words: State Administrative Law, Free of Cost, Endowments Land Certification

\begin{abstract}
Abstrak
Penelitian menganalisis Pasal 22 Peraturan Peemrintah Nomor 13 Tahun 2010 tentang kebijakan pemerintah pembebasan biaya sertifikasi tanah wakaf menurut hukum administrasi negara. Menganalisis alasan pemerintah mengeluarkan kebijakan demikian dalam perspektif HAN. Jenis penelitian library research, memerlukan data sekunder, yang terdiri dari bahan hukum primer, sekunder dan tersier, pendekatannya yuridis normatif, dan analisis datanya kualitatif. Hasil penelitian menjelaskan bahwa pemerintah mengeluarkan kebijakan membebaskan biaya sertifikat tanah wakaf bertujuan untuk memberdayakan tanah wakaf supaya peruntukannya dapat dirasakan masyarakat, percepatan legalitas tanah wakaf, melindungi dan mengamankan serta mengoptimalkan manfaat aset wakaf. Kebijakan ini adalah salah satu upaya memahami perbuatan wakaf yang bermakna
\end{abstract}


ibadah dan berkepastian hukum. Kebijakan pemerintah merupakan implementasi fungsi HAN dalam menciptakan pemerintahan yang bersih dan sesuai asas pemerintahan umum yang baik, yakni; asas legalitas, kesamaan, keadilan, perlindungan hukum, kebijaksanaan, penyelenggaraan kepentingan umum, dan bertindak cermat.

Kata Kunci: Hukum Administrasi Negara, Bebas Biaya, Sertifikasi Tanah Wakaf

\section{A. Pendahuluan}

Tanah merupakan salah satu harta yang bisa diwakafkan, karena kemanfaatan tanah sifatnya abadi, bisa digunakan selamanya. Hal ini sesuai dengan asas hukum wakaf yang menjelaskan bahwa kemanfaatan harta wakaf bersifat abadi, dapat digunakan, diberdayakan dan dikembangkan asalkan tanahnya tidak dihibahkan, dijualbelikan, diwariskan, ditukarkan atau berpindah tangan. ${ }^{1}$ Aturan hukum wakaf tanah pada awalnya berasal dari pranata kegamaan, yakni ajaran hukum Islam yang hidup di tengah aktifitas kegiatan masyarakat. Penegakan hukum wakaf berasal dari perilaku masyarakat yang sudah menjadi kebiasaan yang mapan di tengah-tengah budaya masyarakat.

Namun, ketika terjadi konflik atau sengketa tentang kepastian hukum wakaf dan perlindungan wakif dalam perbuatan wakaf, ternyata hukum wakaf yang hanya berdasarkan pada norma agama belum mampu menyelesaikan masalah, wakaf yang hanya berdasarkan kepercayaan saja, tidak perlu disertifikatkan. ${ }^{2}$ Hal inilah yang menimbulkan problematika hukum harta wakaf tanah, seperti; harta wakaf yang hilang, terbengkalai, dan tidak terpelihara, karena bukti otentik telah terjadinya wakaf yang berupa sertifikasi tanah wakaf tidak ada. Apabila hal ini dibiarkan, akan berakibat chaos/kacau, hukum wakaf tidak bisa dilaksanakan sesuai dengan tujuan dan manfaatnya, warga masyarakat akan pesimis dalam berwakaf. Padahal wakaf adalah salah satu bentuk derma (filantropi) perbuatan baik untuk menginfakkan harta yang dicintainya guna merealisasikan ajaran Allah.

${ }^{1}$ Imam Abi Muslim Ibnu al-Hajj, Shahih Muslim, Jilid III, Beirut: Daar Al-Ihya' Al-Thirosul 'Araby, t.th, hal. 1255.

2 Imam Prayogo, Penyelesaian Sengketa Wakaf, hal. 3, dalam http://jelita249.blogspot.co.id/2009/08/penyelesaian-sengketa-wakaf.html, diunggah hari Rabu, 7 Februari 2018, Jam 12.00 WIB. 
Oleh karena itu, pemerintah mengeluarkan kebijakan dalam mengatur warganya ketika melaksanakan ajaran agamanya khususnya wakaf. Kebijakan tersebut berupa aturan hukum tentang sertifikasi tanah wakaf, yakni; Instruksi Menteri Agama No. 15 Tahun 1989 tentang pembuatan Akta Ikrar Wakaf dan Persertifikatan tanah wakaf, Instruksi Menteri Agama dan Kepala BPN No. 04 Tahun 1990 dan No. 24 Tahun 1990 tentang Sertifikat Tanah Wakaf, Surat Keputusan Bersama Menteri Agama dan Kepala BPN No. 422 dan No. 3/SKB/2004, ${ }^{3}$ tentang Sertifikat Tanah Wakaf. PP Nomor 13 Tahun 2010 Tentang Jenis dan Tarif Atas Jenis Penerimaan Negara Bukan Pajak (PNBP) yang Berlaku Pada Badan Pertanahan Nasional. ${ }^{4}$

Aturan hukum tentang sertifikasi tanah wakaf di atas, merupakan bentuk peraturan pemerintah untuk memberikan pelayanan pada masyarakat tentang sertifikasi tanah wakaf dan mengatur cara-cara organisasi negara ikut serta dalam lalu lintas masyarakat dalam urusan tersebut. Peraturan Pemerintah ditetapkan oleh presiden sebagai badan eksekutif, bukan badan legeslatif dan yudikatif, PP itu memuat aturan yang bersifat umum, yang memberikan tugas khusus pada pejabat administrasi negara untuk memberikan pelayanan baik pada masyarakat. ${ }^{5}$ Para pejabat administrasi negara tersebut diatur oleh hukum administrasi supaya mereka menjalankan tugasnya sesuai dengan hukum telah ditetapkan.

UU No. 25 Tahun 2009 tentang Pelayanan Publik, menjelaskan bahwa masyarakat berhak mendapatkan pelayanan yang berkualitas sesuai dengan asas dan tujuan pelayanan. Menurut Keputusan Menteri Pendayagunaan Aparatur Negara Nomor 63/KEP/M.PAN/7/2003, pelayanan publik adalah segala kegiatan pelayanan yang dilaksanakan oleh penyelenggara pelayanan publik sebagai upaya pemenuhan kebutuhan penerima pelayanan maupun pelaksanaan ketentuan perundang-undangan. Jenis- jenis pelayanan yang dimaksud dalam UU No. 25 Tahun 2009 yaitu pelayanan administratif,

${ }^{3}$ Abdul Ghofur Anshori, Hukum dan Praktif Perwakafan di Indonesia, Yogyakarta, Pilar Media, 2005, hal. 48.

4 https://www.hukumproperti.com/pertanahan/pelayanan-pendaftaran-tanah-sebagai-jenispenerimaan-negara-bukan-pajak-yang-berlaku-pada-badan-pertanahan-nasional-menurut-pp-no13-tahun-2010/, DIUNGGAH HARI MINGGU TANGGAL 4 Februari 2008 jam 22.24

${ }^{5}$ Philipus M. Hadjon,et.al , Pengantar Hukum Administrasi Indonesia, Yogyakarta, Gajah Mada University Press, 2015, hal. 58 
pelayanan barang, dan pelayanan jasa. ${ }^{6}$ Pada pelayanan administratif terdapat pelayanan penerbitan sertifikat tanah wakaf untuk memberikan kepastian hukum pada tanah wakaf yang berfungsi sosial.

Pelayanan sertifikasi tanah wakaf yang dilakukan oleh Badan Pertanahan Nasional berbeda dengan pelayanan sertifikat tanah yang lain. Pasal 22 PP Nomor 13 Tahun 2010 Tentang Jenis dan Tarif Atas Jenis Penerimaan Negara Bukan Pajak (PNBP) yang berlaku pada Badan Pertanahan Nasional, menjelaskan bahwa tarif pelayanan pendaftaran tanah wakaf ditetapkan sebesar Rp 0,00 (nol rupiah) dan tarif pelayanan pendaftaran tanah dari pelayanan pemeliharaan data pendaftaran tanah berupa pelayanan pendaftaran penggantian nazhir ditetapkan sebesar Rp 0,00 (nol rupiah).

Makalah ini akan akan menganalisis Pasal 22 PP Nomor 13 Tahun 2010 tentang kebijakan pemerintah mengenai pembebasan biaya sertifikasi tanah wakaf menurut hukum administrasi negara. Tujuannya untuk mengetahui alasan pemerintah mengeluarkan kebijakan demikian, apakah sesuai dengan asas pelayanan yang baik dalam hukum administrasi negara atau tidak. Manfaatnya supaya dapat diketahui alasan, tujuan, dan manfaat kebijakan pemerintah mengeluarkan Pasal 22 PP Nomor 13 Tahun 2010.

\section{Metode Penelitian}

Jenis penelitian ini library research, yakni penelitian yang mengambil data dari kepustakaan, berupa buku, jurnal, web-side yang berhubungan tema penelitian, tema penelitian tersebut adalah sertifikasi tanah wakaf, PP No. 13 tahun 2010 dan HAN. Data tersebut dikumpulkan, digeneralisir dan dikonsepsikan untuk menyusun laporan hasil penelitian secara sistematis, ilmiah dan dapat dipertanggungjawabkan.

Metode pendekatan penelitian menggunakan yuridis normatif, yuridis artinya penelitian yang berusaha meneliti hal-hal yang menyangkut dasar hukum perundang-undangan yang digunakan yakni UU No. 41/2004 Tentang Wakaf, PP No. 28/1977 tentang wakaf tanah, Peraturan Menteri Agraria dan Tata Ruang/ Kepala Badan Pertanahan Nasional Republik Indonesia Nomor 2 Tahun 2017 Tentang Tata Cara Pendaftaran Tanah Wakaf Di Kementerian Agraria Dan

6 Deddy Prasetya, Efektivitas Pelayanan Dalam Penerbitan Sertifikat Tanah Di Kantor Pertanahan Kabupaten Karo, hal. 2-3 
Adminitrative Law \& Governance Journal. Volume 2 Issue 1, March 2019 ISSN. 2621 - 2781 Online

Tata Ruang/ Badan Pertanahan Nasional, dan Permen Agraria dan Tata Ruang/Kepala Badan Pertanahan Nasional Nomor 2 Tahun 2017 Tentang Tata Cara Pendaftaran Tanah Wakaf di Kementerian Agraria dan Tata Ruang/Badan Pertanahan Nasional. Normatif adalah penelitian untuk mengetahui sejauhmanakah aturan hukum itu berfungsi atau dipahami atau mengatur masyarakat.

Data penelitian yang digunakan adalah data sekunder karena mengambil data dari kepustakaan, sedangkan bahkan hukum yang dibutuhkan bahan hukum primer, sekunder dan tersier. Bahan hukum primer terdiri dari dasar hukum yang digunakan, bahan hukum sekunder terdiri dari sumber referensi atau literasi dari buku atau jurnal yang berkaitan dengan tema penelitian, dan bahan tersier yang berkaitan dengan literasi dari bahan non hukum.

Analisis datanya yakni diskriptif analisis, menguraikan hasil penelitian kemudian dianalisis secara kualitiatif, dengan menggunakan kalimat secara sistematis dan menggunakan prinsip-prinsip ilmiah sehingga bisa diketemukan hasil penelitian sesuai dengan tujuan dan manfaat penelitian. Penelitian diakhiri dengan pengambilan kesimpulan secara deduktif, yakni dari premis mayor ke premis minor, dari pernyataan yang bersifat umum menuju pada pernyataan yang bersifat khusus.

\section{B. Pembahasan}

\section{Sertifikasi Tanah Wakaf}

Sertifikasi tanah wakaf adalah proses penerbitan sertifikat tanah wakaf yang dikeluarkan oleh BPN setelah ada pengajuan mendaftarkan tanah wakaf dari nazhir. ${ }^{7}$ Akibat hukum dari pendaftaran tanah adalah diberikannya surat tanda bukti hak atas tanah yang lazim disebut dengan sertifikat. Sertifikat sebagaimana dijelaskan dalam Pasal 1 Nomor 20 PP No. 24 Tahun 1997 adalah "surat tanda bukti hak sebagaimana dimaksud dalam Pasal 19 Ayat (2) huruf (c) Undang Undang Pokok Agraria untuk hak atas tanah, hak pengelolaan, tanah wakaf, hak milik atas satuan rumah susun, dan hak tanggungannya masing-masing sudah dibukukan dalam

\footnotetext{
${ }^{7}$ Lihat Pasal 10 PP No. 28/1977. Peraturan Menteri Agraria dan Tata Ruang/ Kepala Badan Pertanahan Nasional Republik Indonesia Nomor 2 Tahun 2017 Tentang Tata Cara Pendaftaran Tanah Wakaf Di Kementerian Agraria Dan Tata Ruang/ Badan Pertanahan Nasional Pasal 2.
} 
buku tanah yang bersangkutan". Adapun tujuan dari pensertifikatan tanah sendiri lebih spesifik adalah untuk memperoleh pembuktian yang kuat atau otentik banda wakaf. $^{8}$ Setelah sertifikat tanah terbit, maka kepemilikan tanah wakaf beralih dari milik wakif menjadi milik umat, dan yang bertanggung jawab tentang penggunaan harta wakaf adalah nazhir.

Sertifikat tanah wakaf adalah surat tanda bukti tanah wakaf. ${ }^{9}$ Hal ini dimulai dari penerbitan akta ikrar wakaf oleh PPAIW (Pejabat Pembuat Akta Ikrar Wakaf), yakni KUA (Kantor Urusan Agama) yang berkedudukan sebagai Majlis Ulama Kecamatan. Setelah itu dilanjutkan pendaftaran tanah wakaf oleh nazhir. Peraturan Pemerintah Nomor 24 Tahun 1997 Pasal 1 Ayat (1) menjelaskan bahwa pendaftaran tanah adalah rangkaian kegiatan yang dilakukan oleh pemerintah secara terus menerus, berkesinambungan dan teratur, meliputi pengumpulan, pengolahan, pembukuan, dan penyajian serta pemeliharaan data fisik dan data yuridis dalam bentuk peta dan daftar, mengenai bidang-bidang tanah dan satuan-satuan rumah susun, termasuk pemberian surat tanda bukti hanya bagi bidang-bidang tanah yang sudah ada haknya dan hak milik atas satuan rumah susun serta hak-hak tertentu yang membebaninya.

UUPA telah menggariskan adanya keharusan untuk melaksanakan pendaftaran tanah wakaf di seluruh wilayah Republik Indonesia dan sebagai tindak lanjut Pemerintah mengeluarkan Peraturan Pemerintah Nomor 10 Tahun 1961 yang telah diperbaharuhi dengan Peraturan Pemerintah Nomor 24 Tahun 1997. Dasar utama pendaftaran tanah termasuk tanah wakaf adalah Undang-Undang Pokok Agraria Nomor 5 Tahun 1960 Pasal 19, yaitu :

1) Untuk menjamin kepastian hukum oleh pemerintah diadakan pendaftaran tanah di seluruh wilayah Republik Indonesia menurut ketentuan-ketentuan yang diatur dalam Peraturan Pemerintah.

8 Taufik Hamami, Perwakafan Tanah dalam Politik Hukum Agraria Nasional, Jakarta, PT Tatanusa, 2003, hal 159

9 Permen Agraria dan Tata Ruang/Kepala Badan Pertanahan Nasional Nomor 2 Tahun 2017 Tentang Tata Cara Pendaftaran Tanah Wakaf di Kementerian Agraria dan Tata Ruang/Badan Pertanahan Nasional Pasal 1. 
2) Pendaftaran tersebut dalam ayat (1) pasal ini meliputi :

a) Pengukuran, pemetaan, dan pembukuan tanah

b) Pendaftaran hak atas tanah dan peralihan hak-hak tersebut

c) Pemberian surat-surat tanda bukti hak, yang baru berlaku sebagai alat bukti yang kuat.

3) Pendaftaran tanah diselenggarakan dengan mengingat keadaan negara dan masyarakat, keperluan lalu lintas sosial, ekonomis, serta kemungkinan penyelenggaraannya menurut pertimbangan Menteri Agraria.

4) Dalam Peraturan Pemerintah diatur biaya-biaya yang bersangkutan dengan pendaftaran termasuk dalam ayat (1) di atas, dengan ketentuan bahwa rakyat yang tidak mampu dibebaskan dari pembayaran biayabiaya tersebut.

Tujuan Pendaftaran Tanah adalah; ${ }^{10}$

1. Untuk memberikan kepastian hukum dan perlindungan kepada pemegang hak atas tanah suatu bidang tanah satuan rumah susun dan hak-hak lain yang terdaftar agar dengan mudah dapat membuktikan dirinya sebagai pemegang hak yang bersangkutan.

2. Untuk menyediakan informasi kepada pihak-pihak yang berkepentingan termasuk pemerintah agar dengan mudah dapat memperoleh data yang diperlukan dalam mengadakan perbuatan hukum mengenai bidangbidang tanah dan satuan-satuan rumah susun yang sudah terdaftar.

3. Untuk terselenggaranya tertib administrasi pertanahan.

Berdasarkan penjelasan di atas, memahamkan bahwa pentingnya pendaftaran tanah wakaf, karena dari pendaftaran tanah wakaf ke BPN, maka akan keluarlah sertifikat wakaf yang merupakan bukti telah terjadinya wakaf. Pemerintah sudah berupaya menertibkan aset wakaf, seperti Instruksi Kepala BPN RI Nomor 1 Tahun 2013 Tentang Percepatan Pelaksanaan Program Strategis BPN RI Tahun 2013 di mana

${ }^{10}$ Mohammad Sandia, Analisis Kepastian Hukum Hak Milik Atas Tanah Wakaf Dalam Konsepsi Hukum Agraria Dan Hukum Islam, Jurnal, Al Mashlahah Jurnal Hukum Dan Pranata Sosial Islam, hal. 223. Lihat juga di Pasal 3 Peraturan Pemerintah Nomor 24 Tahun 1997 
tujuan instruksi tersebut untuk legalisasi tanah wakaf sehingga tercipta kepastian hukum atas tanah wakaf tersebut. ${ }^{11}$

Manfaat sertifikasi tanah wakaf yaitu sebagai modal dasar eksisnya lembaga wakaf, menghindari adanya gugatan dari pihak lain atas status tanah wakaf karena mahalnya tanah masa kini dan mendatang, untuk menguatkan status tanah wakaf sebagai fakta sejarah supaya tidak tergusur atau disalahgunakan. ${ }^{12}$ Selain itu, juga memperoleh jaminan dan kepastian hukum mengenai tanah yang diwakafkan. Apabila sertifikat tanah wakaf telah dibalik nama atas nama nazhir, maka nazhir akan memperoleh jaminan dan kepastian hukum untuk memberdayakan wakaf. $^{13}$

Sertikasi tanah wakaf akan diproses di BPN, setelah perbuatan hukum wakaf memenuhi rukun dan syarat yang ditentukan UU Wakaf dan tentunya setelah KUA mengeluarkan Akta Ikrar Wakaf. Proses sertifikasi tanah wakaf akan berlangsung ketika nazhir mendaftarkan tanah wakaf di BPN. Prosedur persertifikatan tanah wakaf oleh BPN telah di atur di Peraturan Menteri Agraria dan Tata Ruang/ Kepala Badan Pertanahan Nasional Republik Indonesia Nomor 2 Tahun 2017 Tentang Tata Cara Pendaftaran Tanah Wakaf Di Kementerian Agraria Dan Tata Ruang/ Badan Pertanahan Nasional. Menurut Peraturan Menteri tersebut menjelaskan bahwa pendaftaran tanah wakaf ada dua, yakni; tanah yang berasal dari hak milik wakif dan tanah yang berasal dari tanah milik adat, uraiannya adalah sebagai berikut; ${ }^{14}$

a. Tanah wakaf yang berasal dari Hak Milik wakif, didaftarkan menjadi tanah wakaf atas nama nazhir, dengan melampirkan surat permohonan, surat ukur, sertifikat hak milik wakif, AIW dan APAIW,

${ }^{11}$ Yamin Lubis, Hukum Pendaftaran Tanah, Mandar Maju, Bandung, 2010, hlm. 273.

12 Moh. Rosyid, Peran Sertifikat Tanah Wakaf Dalam Mengantsipasi Dinamika Zaman: Studi Kasus Madrasah Diniyah Muawanatul Muslimin Di Kudus, Jurnal ZISWAF, Vol. 3, No. 1, Juni 2016, hal. 123.

${ }^{13}$ Lambang Prasetyo, Kedudukan Hukum Pengambilalihan Tanah Wakaf yang Batal Demi Hukum untuk Dibagikan sebagai Harta Warisan dalam Kajian Undang-Undang No. 41 tahun 2004 tentang Wakaf, hal. 89.

14 Peraturan Menteri Agraria dan Tata Ruang/ Kepala Badan Pertanahan Nasional Republik Indonesia Nomor 2 Tahun 2017 Tentang Tata Cara Pendaftaran Tanah Wakaf Di Kementerian Agraria Dan Tata Ruang/ Badan Pertanahan Nasional Pasal 6. 
surat pengesahan nazhir dari KUA, surat pernyataan dari nazhir bahwa tanahnya tidak dalam sengketa, perkara, sita dan tidak dijaminkan. Setelah nazhir memenuhi syarat-syarat yang ditetapkan, maka Kepala Kantor Pertanahan menerbitkan Sertifikat Tanah Wakaf atas nama Nazhir, dan mencatat dalam Buku Tanah dan sertipikat Hak atas Tanah pada kolom yang telah disediakan, dengan kalimat: "Hak atas Tanah ini hapus berdasarkan Akta Ikrar Wakaf/Akta Pengganti Akta Ikrar Wakaf tanggal... Nomor... dan diterbitkan Sertipikat Tanah Wakaf Nomor/... sesuai Surat Ukur tanggal... Nomor... luas... $\mathrm{m}^{2}$ ".

b. Tanah wakaf berasal dari tanah milik adat didaftarkan menjadi tanah wakaf atas nama nazhir, dengan melampirkan surat permohonan, peta bidang tanah/surat ukur, bukti kepemilikan tanah yang sah, AIW dan APAIW, surat pengesahan nazhir dari KUA, surat pernyataan dari nazhir bahwa tanahnya tidak dalam sengketa, perkara, sita dan tidak dijaminkan. setelah memenuhi persyaratan sesuai dengan ketentuan peraturan perundang-undangan, Kepala Kantor Pertanahan menerbitkan keputusan penegasan sebagai tanah wakaf atas nama Nazhir. ${ }^{15}$

2. Kebijakan Pemerintah Mengenai Pembebasan Biaya Sertifikasi Tanah Wakaf

Kebijakan pemerintah mengenai pembebasan biaya sertifikasi tanah wakaf tentunya didasarkan pada beberapa pertimbangan, salah satunya adalah untuk memudahan kepastian hukum pada harta wakaf, sehingga harta wakaf bisa diamankan dan bisa diantisipasi adanya sengketa wakaf di kemudian hari. ${ }^{16}$ Kebijakan pemerintah ini merupakan realisasi dari Pasal 22 PP No.13/2010, yang menjelaskan bahwa tarif pelayanan pendaftaran tanah wakaf ditetapkan sebesar Rp 0,00 (nol rupiah). Dan untuk tarif pelayanan pendaftaran tanah dari pelayanan pemeliharaan data pendaftaran tanah berupa pelayanan pendaftaran penggantian nazhir ditetapkan sebesar Rp 0,00 (nol rupiah). Pasal ini menjelaskan bahwa pemerintah berusaha memberikan pelayanan yang baik kepada

15 Ibid, Pasal 7.

${ }^{16}$ Taufik Hamami, Loc. Cit. 
masyarakat dalam hal biaya sertifikasi wakaf, sebagai bukti telah terjadinya perbuatan wakaf. Dampak hukumnya adalah munculnya legalitas tanah wakaf.

Pembebasan biaya sertifikat yang ditetapkan oleh negara, juga melalui pertimbangan bahwa pemanfaatan harta wakaf ditujukan untuk keperluan peribadatan atau keagamaan dan kepentingan sosial, bukan individu. Hal ini terdapat dalam Pasal 23 PP No.13/2010, yang menjelaskan bahwa terhadap pihak tertentu dapat dikenakan tarif sebesar Rp 0,00 (nol rupiah) dari pelayanan pendaftaran tanah berupa pelayanan pendaftaran tanah untuk pertama kali. Pihak tertentu tersebut adalah masyarakat tidak mampu, instansi pemerintah, badan hukum yang bergerak di bidang keagamaan dan sosial yang penggunaan tanahnya untuk peribadatan, panti asuhan, dan panti jompo. Dengan demikian tarif sertifikasi wakaf nol rupiah karena wakaf termasuk badan hukum yang bergerak di bidang keagamaan dan sosial yang penggunaan tanahnya untuk peribadatan, panti asuhan, dan panti jompo, bahkan lebih luas dari itu..

Kebijakan pemerintah di atas, juga bertujuan untuk memberdayakan tanah wakaf supaya peruntukannya dapat dirasakan masyarakat dalam berbagai bidang, misalnya; pendidikan, kesehatan, kesejahteraan, ekonomi, dan sosial keagamaan. Hal ini sebagai legal policy untuk pemberlakuan hukum supaya dapat membantu pemerintah dalam pencapaian tujuan nasional, ${ }^{17}$ seperti yang terdapat dalam Pembukaan UUD NRI Alenia ke IV, yakni; ${ }^{18}$

a. Melindungi segenap bangsa Indonesia dan seluruh tumpah darah Indonesia

b. Memajukan kesejahteraan umum

c. Mencerdaskan kehidupan bangsa

d. Ikut melaksanankan ketertiban dunia, berdasarkan kemerdekaan, perdamaian abadi dan keadilan sosial.

Berdasarkan penjelasan di atas, dapat dipahami bahwa penetapan peraturan tentang pembebasan beaya sertifikasi wakaf, bertujuan untuk

${ }^{17}$ M. Mahfud MD, Politik Hukum di Indonesia, Jakarta, LP3ES, 1998, hal. 8.

${ }^{18}$ Pembukaan UUD NKRI 1945 Alenia keempat. 
memudahkan dan mempercepat sertifikasi tanah wakaf, memberikan kepastian dan perlindungan hukum bagi banda wakaf, sehingga dapat digunakan untuk mendukung dan membantu pemerintah dalam pencapaian tujuan pembangunan nasional.

\section{Analisis Pasal 22 PP Nomor 13 Tahun 2010 Tentang Kebijakan}

\section{Pemerintah Mengenai Pembebasan Biaya Sertifikasi Tanah Wakaf}

Pengurusan sertifikasi tanah wakaf yang bebas bea merupakan kebijakan pemerintah untuk percepatan legalitas tanah wakaf, sehingga dapat melindungi dan mengamankan aset wakaf, dan ini menjadi landasan upaya berikutnya dalam mengoptimalkan manfaat benda wakaf. Kebijakan ini adalah salah satu upaya mengubah paradigma masyarakat tentang pencatatan harta wakaf. Selama 27 tahun masyarakat memahami bahwa pelaksanaan wakaf hanya berupa lesan saja, tidak perlu memakai akta ataupun sertifikat, karena wakaf adalah ibadah tentang amal harta benda yang hanya ditujukan untuk mengharap ridha Allah. Menurut mereka, adanya akta atau pencatatan wakaf menjadikan keikhlasan beramal menjadi berkurang bahkan sia-sia. ${ }^{19}$ Namun pola pikir seperti itu, ternyata tidak mampu menyelesaikan masalah atau sengketa tentang harta wakaf, bahkan menjadikan harta wakaf tidak bisa terlindungi, tetapi terbengkalai dan rawan sengketa antara nazhir dengan ahli waris wakif atau nazhir dengan ahli warisnya Hal ini berakibat banyak harta wakaf yang tidak terselamatkan atau nyaris hilang kepemilikannya. Dengan demikian hukum wakaf tidak bisa ditegakkan.

Melihat realitas hukum wakaf seperti di atas, menjadikan pemerintah mengeluarkan regulasi berupa kebijakan pemerintah tentang pendaftaran harta wakaf untuk menerbitkan sertifikat tanah wakaf. Pemerintah telah menetapkan regulasi tentang sertifikasi tanah wakaf, yakni; ${ }^{20}$

a. Peraturan Pemerintah No. 28 Tahun 1977 tentang Perwakafan Tanah Milik.

19 Achmad Arief Budiman, Peran KUA dalam Pemberdayaan Perwakafan (Studi Kasus di Kota Semarang), Laporan Penelitian Tidak Diterbitkan, Puslit IAIN Walisongo, 2005, Hal. 3-4.

20 https://www.hukumproperti.com/pertanahan/pelayanan-pendaftaran-tanah-sebagai-jenispenerimaan-negara-bukan-pajak-yang-berlaku-pada-badan-pertanahan-nasional-menurut-pp-no13-tahun-2010/, DIUNGGAH HARI MINGGU TANGGAL 4 Februari 2008 jam 22.24 
b. Instruksi Menteri Agama No. 15 Tahun 1989 tentang pembuatan Akta Ikrar Wakar dan Persertifikatan tanah wakaf.

c. Instruksi Menteri Agama dan Kepala BPN No. 04 tahun 1990 - No. 24 Tahun 1990 tentang Sertifikat Tanah Wakaf.

d. Surat Keputusan Bersama Menteri Agama dan Kepala BPN No. 422 dan No. 3/SKB/2004, tentang Sertifikat Tanah Wakaf.

Ditetapkannya regulasi sertifikasi tanah wakaf di atas, diharapkan mampu mengubah paradigma pemikiran masyarakat tentang kepastian dan perlindungan hukum tanah wakaf. Hal ini sesuai dengan pendapat Roscoe Pound, yang mengatakan bahwa hukum adalah alat untuk merekayasa sosial masyarakat (law as a tool of social enginering), hukum bisa mengubah kehidupan masyarakat sesuai yang dinginkan oleh hukum. ${ }^{21}$ Hukum bisa mengubah paradigma pemikiran masyarakat, karena ada ketimpangan struktur sosial dalam kehidupan masyarakat. Walaupun ketimpangan hukum berasal dari interpretasi atau penafsiran dalil teks keagamaan, namun bisa direformulasikan melalui kajian lebih mendalam tentang ijitihad hukum Islam untuk menegakkan hukum Islam dan menguatkan hukum nasional demi menjadikan perbuatan wakaf berlaku secara efektif dan meminimalisir sengketa.

Menurut hukum Islam, perubahan paradigma pemikiran masyarakat tentang sertifikasi tanah wakaf, menurut penulis merupakan langkah strategis untuk membentuk kemashlahatan dan menolak kemadhorotan. Terjadinya perubahan hukum menurut Ibnu Qoyyim Al-Jauziyah ${ }^{22}$ adalah keniscayaan atau dibolehkan demi mencapai keadilan, adanya perubahan hukum Islam dikarenakan perubahan zaman, tempat, keadaan, dan kebiasaan. Perubahan hukum dalam aturan sertifikasi tanah wakaf merupakan perkembangan dinamika hukum untuk menuju pada keadilan, rahmat, kemaslahatan dan hikmah atau kebijaksanaan. Kemashlahatan artinya kebaikan atau kemanfaatan dan kemadharatan artinya keburukan

21 Bernard L. Tanya dkk, Teori Hukum: Strategi Tertib Manusia Lintas Ruang Generasi, Yogyakarta, Genta Publishing, 2010, hal. 145.

${ }^{22}$ Ibn Qayyim al-Jauziyah, I'lam al-Muawaqi'in 'an Rabbi al- 'Alamin Bairut: Daar al-Fikr, t.th., hal. 14. Lihat pula, Hasbi ash-Shiddiqie, Falsafah Hukum Islam Jakarta: Bulan Bintang, 1993, hal. 444. 
atau kerugian. Perubahan hukum untuk menuju kemashlahatan sesuai dengan kaidah fiqqiyah yang menjelaskan bahwa "Kerusakan itu harus dihilangkan". 23

Bertitik tolak dari penjelasan di atas, dapat dipahami bahwa kebijakan pemerintah tentang sertifikasi tanah wakaf tidak bertentangan dengan hukum Islam, dan harus disosialisasikan kepada umat Islam, supaya mereka berwakaf sesuai dengan aturan pemerintah. Jadi ada harmonisasi atau keselarasan antara hukum agama dengan hukum negara. Hukum negara menetapkan pembebasan sertifikasi tanah wakaf adalah demi kemashlahatan dan menolak kemadharatan, walaupun harus merubah cara berfikir tentang legalitas wakaf dari hukum agama. Latar belakang pemerintah menetapkan tentang pembebasan beaya sertifikasi wakaf adalah mempercepat legalitas tanah wakaf. Sehingga dihindari jangan sampai ada tanah wakaf yang hilang, terlantar karena tidak diberdayakan, dan tidak sesuai dengan peruntukannya.

Pembebasan sertifikasi tanah wakaf, telah mereformulasi pelaksanaan hukum wakaf, dari hukum yang berbentuk lisan atau tidak tertulis menjadi hukum yang berbentuk akta tertulis sebagai bukti outentik telah terjadinya wakaf. Kebijakan pemerintah ini akan selalu berkembang menyertai kehidupan manusia di manapun berada, dan akan berubah sesuai dengan perkembangan manusia. ${ }^{24}$ Dengan demikian konsep pemikiran hukum selalu berkembang seiring dengan perkembangan pemikiran manusia, dan hukum selalu ada untuk mengatur ketertiban manusia. Cicero (106-43 SM), seorang filsuf Romawi menyatakan Ubi Societas ibi ius, artinya di mana ada masyarakat, di sana ada hukum. ${ }^{25}$

Pembebasan beaya sertifikasi tanah wakaf adalah bentuk pelayanan prima yang dilakukan oleh pemerintah kepada masyarakat. Jadi terdapat

${ }^{23}$ Ahmad Sudirman Abbas, Sejarah Qawa'id Fiqhiyyah, Jakarta, Pedoman Ilmu Jaya, 2004, hal. 35

${ }^{24}$ Moh.Mahfud, Bahan Kuliah Politik Hukum, PDIH UNDIP, 2017, hal. 3

${ }^{25}$ Stephen W. Ball, Bibliographical Essay / Legal Positivism, Natural Law, and the Hart/Dworkin Debate, Journal of Criminal Justice Ethics, University of California, San Diego, ISSN: 0731129X (Print) 1937-5948 (Online) Journal homepage: http://www.tandfonline.com/loi/rcre20, hal. 68, upload at 29 June 2016, At: 12:35 WIB. Adji Samekto, Pergeseran Pemikiran Hukum dari Era Yunani Menuju Postmodernisme, Jakarta, Konpress, 2015, hal. v 
hubungan konkrit antara pemerintah dan masyarakat untuk mempercepat legalitas tanah wakaf. Walaupun terdapat berbagai kendala selama proses sertifikasi tanah wakaf, misalnya; adanya syarat-syarat yang ketat pada pendaftaran tanah, sikap nazhir yang tidak sungguh-sungguh dalam upaya melegalkan benda wakaf. Pemerintah tetap melayananinya dengan baik, supaya tujuan atau keinginan pemerintah tercapai dan terwujud masyarakat adil dan makmur. Inilah peran HAN, satu sisi dapat berperan melakukan pengaturan, pelayanan dan perlindungan hukum bagi masyarakat, sisi lain HAN dapat menjalankan fungsinya dalam pengaturan hukum administasi negara supaya masyarakat tidak melakukan perbuatan salah menurut hukum. ${ }^{26}$

Pelayanan masyarakat yang dilakukan oleh pejabat administrasi negara, dalam hal ini BPN, merupakan kewajiban untuk mengelola negara yang baik supaya terwujud kepastian dan perlindungan hukum bagi masyarakat. Taca cara pengelolaan yang baik dijalankan melalui birokrasi yang baik pula, sehingga percepatan tujuan legalitas wakaf bisa tercapai. Oleh karena itu pemerintahan yang baik identik dengan bikrokrasi yang baik, yang berasaskan legalitas dan diskresi dari pejabat negara yang berwenang, apabila tidak ada aturan hukum yang mengaturnya. ${ }^{27}$

Hukum administrasi negara merupakan hukum yang mengatur terselenggaranya pemerintahan yang baik dan mengatur hubungan antara pemerintah dengan masyarakat. Pemerintahpun, dalam hal ini BPN mempunyai kewajiban untuk memberikan pelayanan publik, yakni kegiatan pemberian pelayanan (melayani) keperluan masyarakat yang mempunyai kepentingan pada organisasi itu sesuai dengan aturan pokok dan tatacara yang telah ditetapkan.

Proses sertifikasi tanah wakaf merupakan bentuk pelayanan yang dilakukan atas kerjasama antara Kementrian Agama dengan Kementrian Agraria. Sertifikat tanah wakaf diterbitkan oleh BPN setelah terbitnya Akta Ikrar Wakaf (AIW) atau Akta Pengganti Akta Ikrar Wakaf oleh

${ }^{26}$ Sjacharan Basah, Perlindungan Hukum Terhadap Sikap Tindak, Administrasi Negara, Bandung, Alumni, 1992, hal. 6.

${ }^{27}$ Arfan Faiz Mukhlisi, Reformulasi Diskresi dalam Penataan Hukum Administrasi Negara, Jurnal Rechsvinding, Volume 1 Nomor 1 Januari April 2012, ISSN 209-9089 
KUA, dan tentunya KUA menerbitkan akta wakaf apabila telah terpenuhi rukun dan syarat wakaf. Jadi terdapat hubungan hukum antara pemerintah (KUA dan BPN) dengan masyarakat (nazhir wakaf) dalam rangka legalitas wakaf, dasar yang digunakannya adalah PP Nomor 13 Tahun 2010 Tentang Kebijakan Pemerintah Mengenai Pembebasan Biaya Sertifikasi Tanah Wakaf, serta peraturan lain yang berkaitan dengan pendaftaran dan sertifikasi tanah wakaf.

Fungsi HAN kaitannya dengan Pembebasan beaya sertifikasi tanah wakaf ada tiga, yakni; ${ }^{28}$

a. Fungsi normatif hukum adalah fungsi administrasi negara dalam melakukan berbagai kegiatannya dengan mengfungsikan instrumen yuridis seperti peraturan pemerintah, keputusan, penetapan, peraturan kebijaksanaan, dan sebagainya. Hal ini menunjukkan bahwa hukum administrasi negara sebagai hukum publik berfungsi mengimplementasikan peraturan perundang-undangan kepada pegawai administrasi negara dan masyarakat dalam melakukan sertifikasi tanah wakaf.

b. Fungsi instrumental hukum adalah fungsi administrasi negara untuk menemukan dan menerapkan peraturan hukum. Peraturan itu tidak hanya terdapat dalam undang-undang saja, tetapi dalam kombinasi peraturan-peraturan dan keputusan-keputusan Tata Usaha Negara (TUN) yang satu dengan yang lain, yang saling berkaitan. Pada umumnya ketentuan undang-undang yang berkaitan dengan HAN hanya memuat norma-norma pokok atau umum, sementara periciannya diserahkan pada peraturan pelaksanaan. Penyerahan ini dikenal dengan istilah terugtred atau sikap mundur dari pembuat undang-undang. Begitu juga dalam legalitas tanah wakaf, secara umum ada dalam UU Wakaf, namun aturan pelaksanaannya ada dalam PP, Instruksi Kementeri Agraria, Instruksi Kementrian Agama, dan Kepala BPN.

${ }^{28}$ Philipus M. Hadjon, dalam Ali Abdul Wakhid, Kedudukan Hukum Administrasi Negara Dalam Tata Hukum Indonesia, hal. 6-8 
c. Fungsi perlindungan hukum adalah fungsi administrasi negara yang melindungi aparatur negara dan warga negara terhadap sikap dan tindak yang baik dan benar menurut hukum, baik yang tertulis maupun yang tidak tertulis. Di dalam negara hukum Pancasila, perlindungan hukum bagi rakyat diarahkan kepada usaha-usaha untuk mencegah terjadinya sengketa antara pemerintah dan rakyat, menyelesaikan sengketa antara pemerintah dan rakyat secara musayawarah serta peradilan merupakan sarana terakhir dalam usaha menyelesaikan sengketa antara pemerintah dengan rakyat.

Berdasarkan pemaparan fungsi-fungsi HAN di atas, dapatlah disebutkan bahwa dengan menerapkan fungsi-fungsi HAN ini akan tercipta pemerintahan yang bersih yang sesuai dengan asas-asas pemerintahan umum yang baik, yakni asas legalitas, kesamaan, keadilan, perlindungan hukum kebijaksanaan, penyelenggaraan kepentingan umum, dan bertindak cermat. Dengan demikian kebijakan pemerintah tentang pembebasan biaya sertifikasi tanah wakaf sesuai dengan prinsip-prinsip hukum administrasi negara.

\section{Simpulan}

Berdasarkan uraian di atas, dapat disimpulkan bahwa Pertama, Sertifikasi tanah wakaf adalah proses penerbitan sertifikat tanah wakaf yang dikeluarkan oleh BPN setelah ada pengajuan mendaftarkan tanah wakaf dari nazhir. Dasar hukum persertifikatan tanah wakaf di atur di Peraturan Menteri Agraria dan Tata Ruang/ Kepala Badan Pertanahan Nasional Republik Indonesia Nomor 2 Tahun 2017 Tentang Tata Cara Pendaftaran Tanah Wakaf Di Kementerian Agraria Dan Tata Ruang/ Badan Pertanahan Nasional.

Kedua, Manfaat Kebijakan pemerintah tentang pembebasan beaya sertifikasi tanah wakaf berdasarkan Pasal 22 dan 23 PP No.13/2010, yakni; dapat memudahkan dan mempercepat sertifikasi tanah wakaf, memberikan kepastian dan perlindungan hukum bagi tanah wakaf, dapat membantu pemerintah dalam pencapaian tujuan pembangunan nasional. Ketiga, Kebijakan pemerintah dalam pembebasan beaya tanah wakaf merupakan implementasi fungsi HAN dalam menciptakan pemerintahan yang bersih yang sesuai dengan asas-asas pemerintahan umum yang baik, yakni asas legalitas, 
kesamaan, keadilan, perlindungan hukum kebijaksanaan, penyelenggaraan kepentingan umum, dan bertindak cermat.

Saran yang layak disampaikan adalah memunculkan kesadaran bersama bahwa wakaf adalah ibadah yang berdimensi sosial, diperlukan kepastian dan perlindungan hukum bagi wakif supaya tujuan wakaf dapat tercapai dan manfaat wakaf dapat dirasakan oleh masyarakat. Kebijakan pemerintah terkait dengan pembebasan biaya sertifikasi tanah wakaf hendaknya dapat dilaksanakan oleh para pihak yang terlibat wakaf.

\section{Daftar Pustaka}

Al-Hajj, Imam Abi Muslim Ibnu, t.th, Shahih Muslim, Jilid III, Beirut: Daar Al-Ihya' Al-Thirosul 'Arab.

Anshori, Abdul Ghofur, 2005, Hukum dan Praktif Perwakafan di Indonesia, Yogyakarta, Pilar Media.

Basah, Sjacharan, 1992, Perlindungan Hukum Terhadap Sikap Tindak, Administrasi Negara, Bandung, Alumni.

Hamami, Taufik, 2003, Perwakafan Tanah dalam Politik Hukum Agraria Nasional, Jakarta, PT Tatanusa.

https://www.hukumproperti.com/pertanahan/pelayanan-pendaftaran- tanahsebagai-jenis-penerimaan-negara-bukan-pajak-yang-berlaku-padabadan-pertanahan-nasional-menurut-pp-no-13-tahun-2010/, diunggah hari minggu tanggal 4 Februari 2008 jam 22.24 WIB.

https://www.hukumproperti.com/pertanahan/pelayanan-pendaftaran-tanahsebagai-jenis-penerimaan-negara-bukan-pajak-yang-berlaku-padabadan-pertanahan-nasional-menurut-pp-no-13-tahun-2010/, Diunggah Hari Minggu Tanggal 4 Februari 2008 Jam 22.24 Wib.

Imam Prayogo, Penyelesaian Sengketa Wakaf, hal. 3, dalam http://jelita249.blogspot.co.id/2009/08/penyelesaian-sengketawakaf.html, diunggah hari Rabu, 7 Februari 2018, Jam 12.00 WIB.

L. Tanya, Bernard, dkk, 2010, Teori Hukum: Strategi Tertib Manusia Lintas Ruang Generasi, Yogyakarta, Genta Publishing.

Lambang Prasetyo, Kedudukan Hukum Pengambilalihan Tanah Wakaf yang Batal Demi Hukum untuk Dibagikan sebagai Harta Warisan dalam Kajian Undang-Undang No. 41 tahun 2004 tentang Wakaf, dalam http://journals.usm.ac.id/index.php/jic/article/download/545/358,diungg ah hari Rabu, 7 Januari 2018, jam 12.45. WIB.

Lubis, Yamin, 2010, Hukum Pendaftaran Tanah, Bandung, Mandar Maju.

M. Hadjon, Philipus, dalam Ali Abdul Wakhid, Kedudukan Hukum Administrasi Negara Dalam Tata Hukum Indonesia, Jurnal Letigasi, Vol. 2 No.2. April 2011, Sekolah Tinggi Ilmu Hukum AMSIR, Parepare, Sulawasi Selatan.

M. Hadjon, Philipus, et.al , 2015, Pengantar Hukum Administrasi Indonesia, Yogyakarta, Gajah Mada University Press. 
MD, M. Mahfud, 1998, Politik Hukum di Indonesia, Jakarta, LP3ES.

Mukhlisi, Arfan Faiz, Reformulasi Diskresi dalam Penataan Hukum Administrasi Negara, Jurnal Rechsvinding, Volume 1 Nomor 1 Januari April 2012, ISSN 209-9089.

Permen Agraria dan Tata Ruang/Kepala Badan Pertanahan Nasional Nomor 2 Tahun 2017 Tentang Tata Cara Pendaftaran Tanah Wakaf di Kementerian Agraria dan Tata Ruang/Badan Pertanahan Nasional.

PP No. 28/1977. Peraturan Menteri Agraria dan Tata Ruang/ Kepala Badan Pertanahan Nasional Republik Indonesia Nomor 2 Tahun 2017 Tentang Tata Cara Pendaftaran Tanah Wakaf Di Kementerian Agraria Dan Tata Ruang/ Badan Pertanahan Nasional.

Rosyid, Moh, 2016, Peran Sertifikat Tanah Wakaf Dalam Mengantsipasi Dinamika Zaman: Studi Kasus Madrasah Diniyah Muawanatul Muslimin Di Kudus, Jurnal ZISWAF, Vol. 3, No. 1, Juni 2016.

Sandia, Mohammad, Analisis Kepastian Hukum Hak Milik Atas Tanah Wakaf Dalam Konsepsi Hukum Agraria Dan Hukum Islam, Jurnal, Al Mashlahah Jurnal Hukum Dan Pranata Sosial Islam, Vol. 2. No. 3. PISSN: 2339-2800 E-ISSN: 2581-2556, Akhwalus Syahsyiah AlHidayah, Bogor.

UU No. 41/2004 Tentang wakaf

UUD NKRI 1945

W. Ball, Stephen, 2015, Bibliographical Essay / Legal Positivism, Natural Law, and the Hart/Dworkin Debate, Journal of Criminal Justice Ethics, University of California, San Diego, ISSN: 0731-129X (Print) 19375948 (Online) Journal homepage: http://www.tandfonline.com/loi/rcre20, upload at 29 June 2016, At: 12:35 WIB. 